\title{
Inherent Dangers in Orogenital Sex During Pregnancy
}

\author{
Giovanni Sisti, Sorbi Flavia, Fambrini Massimiliano \\ Department of Science for Woman and Child Health, University of Florence, Florence, Italy
}

\section{A B S T R A C T}

Coitus and cunnilingus during pregnancy are generally safe; whereas orogenital sex involving vaginal air insufflations can be very dangerous, causing even the death of the women. We carried out a search of case reports and reviews concerning air embolism during pregnancy due to orogenital sex. Physicians consultations must cover all the rules of safe sexual behavior, including avoidance of vaginal air insufflations in the third trimester.

KEY WORDS: Air embolism, cunnilingus, orogenital sex, pregnancy

\section{INTRODUCTION}

Air embolism produced by vaginal insufflations is uncommon, but life threatening. ${ }^{[1,2]}$ One of the causes can be orogenital sex, since it can cause air insufflations. The vagina of a pregnant woman is a highly distensible organ and can accommodate more than 1 liter of air. ${ }^{[3,4]}$ The air can then separate the amniotic membrane from the uterine wall and pass into the mother's venous circulation via subplacental sinuses. ${ }^{[2]}$ The air embolus follows the inferior vena cava to the mother's right heart, thus resulting in mechanical obstruction of the right ventricular outflow tract, leading to cardiac arrhythmias and pulmonary embolism..$^{[5]}$ The air can then enter the arterial circulation via an atrial septal defect, present in about 25\% of adults. ${ }^{[6]}$ Bubbles can finally reach the mother's brain with fatal consequences. Moreover bubbles have more delayed and diffuse actions, the indirect or surface activity effect. This relates to the blood-bubble interface at which certain circulating enzymes change their configuration and thus their biochemical activity. The effects of this includes endothelial edema, platelet thrombi, increased capillary permeability, and the release of biologic mediators such as smooth muscle acting factor ${ }^{[2]}$ This phenomenon could explain the coagulopathy and bronchospasm observed in some patients. ${ }^{[5]}$ Appropriate and prompt therapy for air embolism is necessary to avoid maternal and intrauterine fetal death.

\begin{tabular}{|l|l|}
\hline \multicolumn{2}{|c|}{ Access this article online } \\
\hline Quick Response Code & Website: \\
\hline & www.jbcrs.org \\
\hline & \\
\hline
\end{tabular}

\section{MATERIALS AND METHODS}

We carried out an electronic search of case reports and reviews concerning air embolism during pregnancy due to orogenital sex. The following electronic databases were searched: MEDLINE, Google Scholar, and EMBASE. The following key words were used: Air embolism, pregnancy, pregnant, orogenital sex, oral sex, and adult pulmonary distress syndrome. The search strategy had no language restrictions. We manually searched reference lists of journal articles to locate additional studies. No written protocol of this review has been made or published. Two reviewers independently selected studies for inclusion.

\section{RESULTS}

Our search ended in 16 articles [Table 1],,$^{[1-5,7-17]}$ two of which contained a review of literature data ${ }^{[1,2]}$ and one $e^{[12]}$ contained multiple case report. The most recent review has been made in $1983 .^{[2]}$

The average age of women was 20.2 years, and only one was older than 30 years. Average and median gestation age was 29 weeks. The setting of the incident is similar to all the cases. The partner was blowing air into the vagina for a few minutes during orogenital sex. In all the cases, the air embolism occurred immediately after the sexual act. The presentation symptoms varied from neurologic coma and dizziness to epilepsy and loss of

Address for correspondence Dr. Giovanni Sisti,

Department of Science for Woman and Child Health, Careggi Hospital, University of Florence, Viale Morgagni 85, 50134, Florence, Italy. E-mail: giovanni83@email.it 


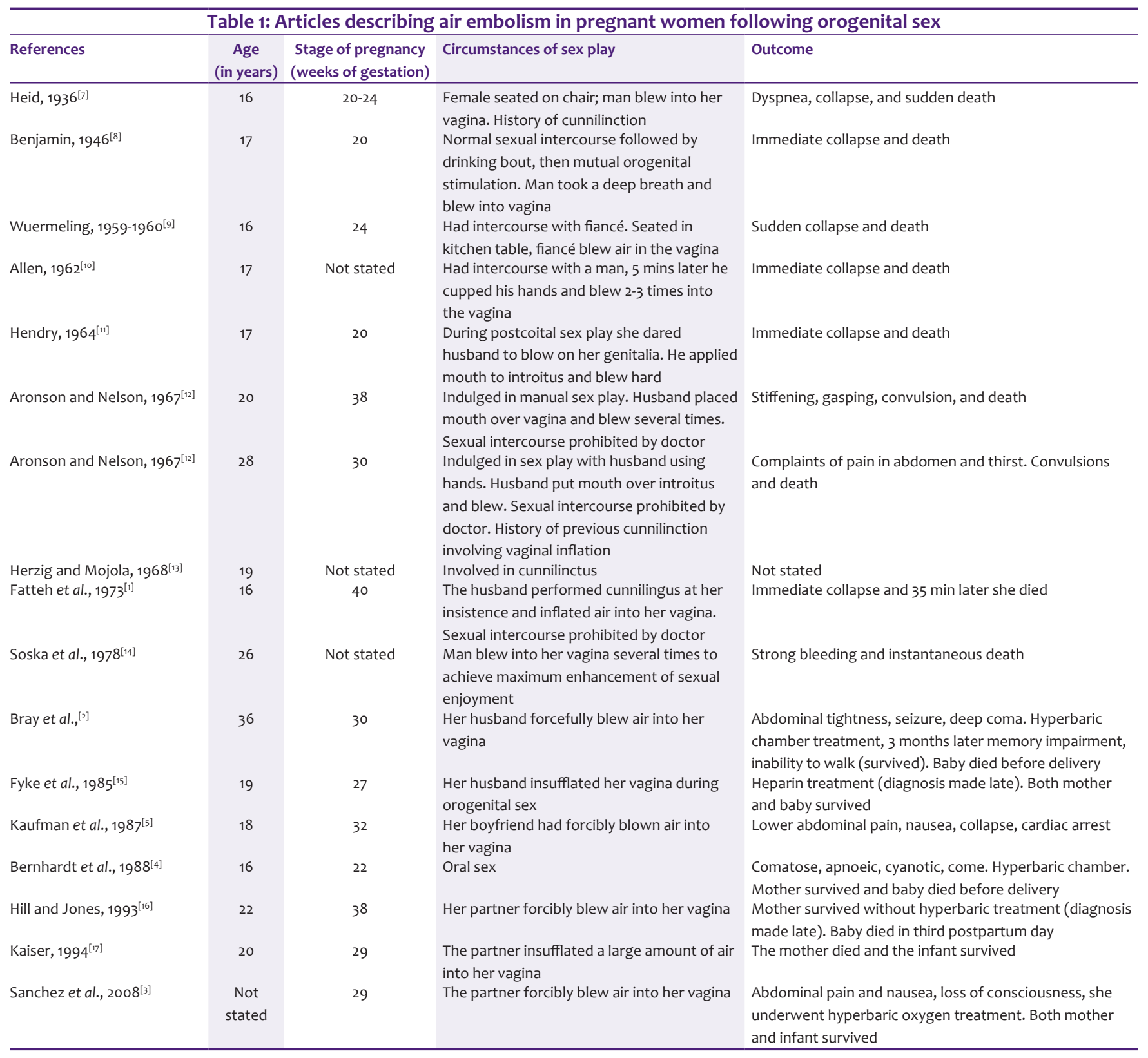

consciousness. In the reports of Aronson and Nelson, ${ }^{[12]}$ the women were suggested by their doctor not to have intercourse during pregnancy. Air embolism is associated with high risk of death. Four women survived, twelve died, and in one case report the outcome of air embolism was not stated.

The autopsies in the majority of the dead women found air bubbles in the right heart and pulmonary tissue, in the most serious cases they even found subcutaneous bubbles.

\section{DISCUSSION}

The occurrence of air embolism during pregnancy is uncommon. It can be due to vaginal douching with a bulb syringe or effervescent fluid, powder insufflations as a treatment of vaginal infection, ${ }^{[7]}$ and by attempts at criminal illegal abortion. ${ }^{[6]}$

Our data suggests that third trimester pregnancy seems to be the most at risk for this event. No comorbidities were observed in the majority of the cases. Regardless its etiology, treatment of air embolism during pregnancy is not yet defined.

Three articles reported hyperbaric chamber treatment as a specific and highly effective therapy for air embolism of any etiology. However, its effectiveness depends on the time between the incident and the treatment. The shorter is the time, the better is the result. In all of these three 
cases, the mother survived, and in two-third the infants survived too.

Nevertheless there are two case $\mathrm{e}^{[15,16]}$ in which the mother survived without hyperbaric chamber treatment. Fyke $e^{[15]}$ describes initial intravenously heparin administration; only later, when the husband of the patient revealed that his wife's sudden collapse had occurred during orogenital sex, physicians decided to discontinue heparin administration. The woman suddenly improved and was discharged 6 days after; in this case no hyperbaric therapy was given. In contrast, the patient described by Hill ${ }^{[16]}$ survived with only support therapy, having the exact diagnosis only in the third day in hospital.

The best treatment seems to be support therapy and praecox use of hyperbaric chamber.

Considering the average age of the women, this pathologic event seems to be related to youth. This can be explained by major prevalence of this type of sexual behavior in young ladies. In some cases, orogenital sex was adopted since intercourse was prohibited by physicians.

Recently, it has been accepted that coitus and cunnilingus are safe for pregnant women, whereas forceful blowing of air into the vagina can be life-threatening. ${ }^{[18]}$

The clinical diagnosis of acute air embolism can be strongly suggested by history of orogenital sex. Unfortunately, in many of the cases we reviewed, during patient history taking, the correct description of the sexual act was omitted.

In conclusion, we believe that physicians' consultations must cover all the rules of safe sexual behavior, including avoidance of vaginal air insufflations in the third trimester.

Besides, air embolism should be considered in the differential diagnosis of pregnant patient with a history of orogenital sex followed by dyspnea, abdominal pain, and loss of consciousness.

\section{REFERENCES}

1. Fatteh A, Leach WB, Wilkinson CA. Fatal air embolism in pregnancy resulting from orogenital sex play. Forensic Sci 1973;2:247-50.

2. Bray P, Myers RA, Cowley RA. Orogenital sex as a cause of nonfatal air embolism in pregnancy. Obstet Gynecol 1983;61:653-7.

3. Sanchez JM, Milam MR, Tomlinson TM, Beardslee MA. Cardiac troponin I elevation after orogenital sex during pregnancy. Obstet Gynecol 2008;111 (2 Pt 2):487-9.

4. Bernhardt TL, Goldmann RW, Thombs PA, Kindwall EP. Hyperbaric oxygen treatment of cerebral air embolism from orogenital sex during pregnancy. Crit Care Med 1988;16:729-30.

5. Kaufman BS, Kaminsky SJ, Rackow EC, Weil MH. Adult respiratory distress syndrome following orogenital sex during pregnancy. Crit Care Med 1987;15:703-4.

6. Gronert GA, MessickJM Jr, Cucchiara RF, Michenfelder JD. Paradoxical air embolism from a patent foramen ovale. Anesthesiology 1979;50:548-9.

7. Heid. Ein eigenartiger Todesfalle in der Schwangerschaft durch Luftembolie. Oeff Gesundheitsdienst 1936; A2. p. 720-8.

8. Benjamin $\mathrm{H}$. A case of of fatal air embolism through an unusual sexual act (medical and legal implications). J Clin Exp Psychopathol 1946;7:815-20.

9. Wuermeling HB. Fatal air embolism in a pregnant subject caused by vaginal air insufflation with the mouth. Dtsch Z Gesamte Gerichtl Med 1959-1960;49:696-9.

10. Allen C. A Textbook of Psychosexual Disorders. London: Oxford University Press; 1962. p. 80.

11. Hendry WT. An unusual case of air embolism. Med Sci Law 1964;4:179-81.

12. Aronson ME, Nelson PK. Fatal air embolism in pregnancy resulting from an unusual sexual act. Obstet Gynecol 1967;30:127-30.

13. Herzig N, Mojola J. Death from air embolism during pregnancy. Obstet Gynecol 1968;32:732.

14. Soska J, Uher M, Pilka L. Unusual noncoital activity in pregnancy with fatal outcome. Cesk Gynekol 1978;43:779-80.

15. Fyke FE $3^{\text {rd }}$, Kazmier FJ, Harms RW. Venous air embolism. Life-threatening complication of orogenital sex during pregnancy. Am J Med 1985;78:333-6.

16. Hill BF, Jones JS. Venous air embolism following orogenital sex during pregnancy. Am J Emerg Med 1993;11:155-7.

17. Kaiser RT. Air embolism death of a pregnant woman secondary to orogenital sex. Acad Emerg Med 1994;1:555-8.

18. White SE, Reamy K. Sexuality and pregnancy: A review. Arch Sex Behav 1982;11:429-44.

How to cite this article: Sisti G, Flavia S, Massimiliano F. Inherent dangers in orogenital sex during pregnancy. J Basic Clin Reprod Sci 2013;2:3-5.

Source of Support: Nil, Conflict of Interest: None declared 